\title{
ANALISIS FAKTOR YANG BERHUBUNGAN DENGAN KEBERHASILAN BERHENTI MEROKOK DI BANJAR AGUNG LAMPUNG SELATAN
}

\author{
Eka Nur Janah ${ }^{1}$, Dhiny Easter Yanti ${ }^{2}$, Fitri Eka Sari ${ }^{3}$ \\ Universitas Malahayati Bandar Lampung \\ ekanurjanah1303@gmail.com ${ }^{1}$, dhiny.easter@gmail.com²
}

\begin{abstract}
Smoking become the biggest threaten in public health world because it kills more than 8 millions people every year. More than $60 \%$ smokers indicates that they are mean to quitting, and more than $40 \%$ has done any kind of effort to quit in 12 months before survey taken (World Health Organization, 2019). The aim of this study is to analyze factor related to quit smoking success in banjar agung south lampung. This study use cross sectional approach, with population 231 ex-smoker/KK took study sample 75. Sample collected used purposive sampling technique with data collected use questionnaire and data analyze used chi square test. The Based from the result of bivariate analysis with chi square test, household member that does not smoking ( $p$-value $=0,001 ; O R=6,460)$ and perceived benefit ( $p$ value $=0,003 ;$ OR=5,417) shows significant correlation with quit smoking success. Meanwhile knowledge ( $p$-value $=0,432)$ and perceived barrier ( $p$-value $=0,101)$ shows no significant correlation with quit smoking success. Someone's quit smoking success influenced by closest related smoking behavior and beliefs about benefit from quit smoking. Hopefully good knowledge is in the line with community behavior, so that this study can be the basic data in increasing health promotion about the dangerous of smoking.
\end{abstract}

Keywords $\quad$ : Household, knowledge, perceived barrier, perceived benefit, success

\begin{abstract}
ABSTRAK
Rokok menjadi ancaman terbesar kesehatan masyarakat dunia karena telah menewaskan lebih dari 8 juta orang setiap tahunnya. Lebih dari $60 \%$ perokok mengindikasikan bahwa mereka bermaksud untuk berhenti, dan lebih dari $40 \%$ telah berusaha untuk berhenti dalam 12 bulan sebelum survei dilakukan. Tujuan penelitian ini untuk menganalisis faktor yang berhubungan dengan keberhasilan berhenti merokok di Banjar Agung Lampung Selatan. Penelitian ini menggunakan pendekatan cross sectional, dengan populasi 231 mantan perokok/KK didapatkan sampel penelitian 75 . Penentuan sampel menggunakan teknik purposive sampling dengan pengumpulan data menggunakan kuesioner dan analisis data menggunakan uji chi square. Hasil analisa bivariat dengan uji statistik chi square, anggota rumah tangga yang tidak merokok ( $\mathrm{p}$-value $=0,001 ; \mathrm{OR}=6,460)$ dan perceived benefit ( $\mathrm{p}$ value $=0,003 ; \mathrm{OR}=5,417$ ) menunjukkan ada hubungan yang signifikan dengan keberhasilan berhenti merokok. Sedangkan pengetahuan ( $\mathrm{p}$-value $=0,432)$ dan perceived barrier $(\mathrm{p}$-value $=0,101)$ menunjukkan tidak ada hubungan yang signifikan dengan keberhasilan berhenti merokok. Keberhasilan berhenti merokok seseorang dipengaruhi oleh perilaku merokok orang terdekat dan kepercayaannya tentang manfaat dari berhenti merokok. Diharapkan pengetahuan yang baik dapat berbanding lurus dengan perilaku masyarakat, sehingga penelitian ini dapat menjadi data dasar dalam meningkatkan promosi kesehatan tentang bahaya merokok.
\end{abstract}

Kata Kunci : Anggota Rumah, Keberhasilan, Pengetahuan, Perceived Barrier, Perceived Benefit

\section{PENDAHULUAN}

Rokok menjadi ancaman terbesar kesehatan masyarakat dunia karena telah menewaskan lebih dari 8 juta orang setiap tahunnya. Terdapat 1,1 miliar perokok dewasa di seluruh dunia dan 367 juta merupkan pengguna tembakau tanpa asap, serta banyak dari mereka berkeinginan untuk berhenti merokok. Rata-rata diseluruh negara saat survei tembakau 
pada orang dewasa, lebih dari $60 \%$ perokok mengindikasikan bahwa mereka bermaksud untuk berhenti, dan lebih dari $40 \%$ telah berusaha untuk berhenti dalam 12 bulan sebelum survei dilakukan (World Health Organization, 2019). Hal ini belum tercapai pada Wilayah Asia Tenggara termasuk di dalamnya negara Indonesia. Hampir 586 miliar batang rokok diproduksi di negara-negara ASEAN pada tahun 2016 dan 1,327 miliar batang rokok dihisap oleh orang dewasa setiap harinya. Menurut WHO, Wilayah Asia Tenggara merupakan rumah bagi seperempat populasi dunia. Terdapat 246 juta perokok dan 290 juta pengguna tembakau tanpa asap, menjadikannya salah satu wilayah konsumen tembakau terbesar dengan menampung seperempat perokok dunia (Lian \& Dorotheo, 2018).

Menurut data Riset Kesehatan Dasar tahun 2018 menunjukkan bahwa prevalensi merokok secara nasional sebesar 28,8\% (Kementerian Kesehatan Republik Indonesia, 2018). Presentase jumlah penduduk yang merokok usia $\geq 15$ tahun di Indonesia tahun 2019 pada pedesaan sebesar $30,84 \%$ dan perkotaan sebesar 27,64\%. Provinsi Lampung presentase jumlah penduduk yang merokok usia $\geq 15$ tahun sebesar $34,39 \%$, yang menjadi presentase tertinggi jumlah penduduk yang merokok di pedesaan dan perkotaan dibandingkan provinsi lain (Badan Pusat Statistik, 2019). Kabupaten Lampung Selatan prevalensi merokok pada penduduk usia $\geq 10$ tahun sebesar $31,06 \%$ dengan $28,05 \%$ perokok setiap hari dan 3,01\% perokok kadang-kadang (Kemenkes RI, 2018). Jumlah penduduk di desa Banjar Agung 2.358 jiwa dengan jumlah rumah sebanyak 659. Banjar Agung memiliki jumlah perokok terbanyak ketiga dari 9 desa yang ada di wilayah kerja Puskesmas Banjar Agung yaitu $65 \%$ yang didapat dari data hasil survei dan pengawasan serta pemantauan Gerakan Masayarakat Hidup Sehat (Germas) pada 100 penduduk per desa
(Puskesmas Rawat Inap Banjar Agung, 2020).

Germas merupakan aksi nyata mengajak masyarakat untuk hidup sehat, karena kesehatan masyarakat erat kaitannya dengan perilaku dan lingkungan (Kementerian Kesehatan Republik Indonesia, 2017). Merokok merupakan kebiasaan yang akan memberikan efek buruk bagi kesehatan. Berhenti merokok menjadi salah satu bagian terpenting dalam gerakan hidup sehat karena merokok tidak hanya berdampak pada perokok itu sendriri namun juga orang yang berada disekitar perokok. Namun, salah satu indikator Germas ini belum tercapai dengan baik di desa Banjar Agung. Tujuan penelitian ini diketahui faktor-faktor yang berhubungan dengan keberhasilan berhenti merokok di Banjar Agung Lampung Selatan.

\section{METODE}

Penelitian ini menggunakan metode penelitian kuantitatif dengan desain penelitian cross sectional. Penelitian ini dilakukan pada bulan Juni-Juli 2021 di Banjar Agung, Lampung Selatan. Pemilihan responden dalam penelitian ini menggunakan teknik purposive sampling dengan pengumpulan data menggunakan instrument penelitian berupa kuesioner. Populasi dalam penelitian ini sebanyak 231 mantan perokok/KK. Cara pengambilan sampel dalam penelitian ini menggunakan teknik sampling yaitu nonprobability sampling didapat hasil sebanyak 68 sampel minimum. Pengambilan sampel dilebihkan $10 \%$ untuk menghindari sampling error sehingga menjadi 75 responden.

Variabel dalam penelitian ini yaitu keberhasilan berhenti merokok sebagai variabel terikat, dan anggota rumah tangga yang tidak merokok, pengetahuan, perceived benefit, serta perceived barrier sebagai variabel bebas. Pengumpulan data dalam penelitian ini, dari segi sumber datanya maka peneliti menggunakan 
sumber data primer dan sumber data sekunder. Sumber data primer dalam penelitian ini yaitu data yang didapat secara langsung dari responden penelitian (mantan perokok) terkait variabel penelitian yaitu anggota rumah tangga yang tidak merokok, pengetahuan, perceived benefit dan perceived barrier yang dilakukan dengan pengisian kuesioner dengan wawancara. Sementara itu data sekunder yaitu data merokok dari laporan hasil evaluasi program promosi kesehatan dan data survei PHBS serta pengawasan dan pemantauan Germas di puskesmas Banjar Agung, Lampung Selatan. Teknik pengumpulan data dalam penelitin ini dengan cara wawancara menggunakan kuesioner yang telah diuji validitas dan reliabilitasnya. Jumlah kuesioner dalam penelitian ini sebanyak 19 pertanyaan yang mencakup semua variabel terkait.

Data yang diperoleh dari hasil wawancara menggunakan instrument penelitian yaitu kuesioner, kemudian diolah sehingga menjadi sebuah informasi. Pengelolaan data dalam penelitian ini yaitu, penyuntingan kelengkapan jawaban (editing), pengkodean (coding), entry data dan yang terakhir pembersihan data kosong untuk menghindari missing (cleaning).

\section{HASIL}

Berdasarkan tabel 1 dapat dilihat bahwa, dari 75 responden terdapat 48 (64\%) responden yang memiliki anggota rumah tangga tidak merokok dan sebanyak $27(36 \%)$ lainnya tidak ada anggota rumah tangga yang tidak merokok. Distribusi variabel pengetahuan dapat diketahui bahwa dari 75 responden, terdapat 42 (56\%) responden dengan tingkat pengetahuan baik dan sebanyak $33(44 \%)$ responden dengan pengetahuan kurang baik. Distribusi variabel perceived benefit dapat dilihat bahwa dari 75 responden penelitian, terdapat $51(68 \%)$ responden yang memiliki persepsi positif tentang manfaat berhenti merokok (perceived benefit) dan 24 (32\%) lainnya tidak memiliki persepi positif terhadap manfaat berhenti merokok. Distribusi variabel perceived barrier dapat dilihat bahwa dari 75 responden penelitian, terdapat $54(72 \%)$ responden yang tidak mendapati hambatan untuk berhenti merokok (perceived barrier) dan 21 (27\%) mendapati beberapa hambatan untuk dapat berhenti merokok

\section{Tabel 1. Distribusi Frekuensi di Banjar} Agung Lampung Selatan

\begin{tabular}{lcc}
\hline Variabel & Frekuensi & Presentase (\%) \\
\hline $\begin{array}{l}\text { Anggota Rumah Tangga yang Tidak } \\
\text { Merokok }\end{array}$ & \\
& & \\
Ada & 48 & 64 \\
Tidak Ada & 27 & 36 \\
\hline Pengetahuan & & \\
Baik & 42 & 56 \\
Kurang Baik & 33 & 44 \\
\hline $\begin{array}{c}\text { Perceived } \\
\text { Benefit }\end{array}$ & & \\
Ada & 51 & 68 \\
Tidak ada & 24 & 32 \\
\hline $\begin{array}{c}\text { Perceived } \\
\text { barrier }\end{array}$ & & \\
Tidak ada & 54 & 72 \\
Ada & 21 & 27 \\
\hline Total per & 75 & 100 \\
variabel & & \\
\hline
\end{tabular}

Berdasarkan tabel 2, hasil analisis hubungan antara anggota rumah yang tidak merokok dengan keberhasilan berhenti merokok diperoleh bahwa ada sebanyak 38 $(79,2 \%)$ responden dengan anggota rumah tangga yang tidak merokok berhasil berhenti merokok. Sedangkan responden yang tidak ada anggota rumah yang tidak merokok ada sebanyak $10 \quad(37 \%)$ yang berhasil berhenti merokok. Hasil uji statistikchi square, diperoleh nilai $\mathrm{p}$ value $=0,001(<0,05)$ maka dapat disimpulkan bahwa ada hubungan yang signifikan antara anggota rumah tangga yang tidak merokok dengan keberhasilan berhenti merokok. Hasil analisis diperoleh pula nilai Odds Rasio $(\mathrm{OR})=6,460$, artinya responden dengan anggota rumah yang tidak merokok memiliki peluang 6,460 
kali untuk berhasil berhenti merokok dibandingkan dengan yang tidak ada anggota rumah yang tidak merokok. Hasil analisis hubungan antara pengetahuan dengan keberhasilan berhenti merokok diperoleh bahwa ada sebanyak $29(69,0)$ responden yang memiliki pengetahuan baik dapat berhasil berhenti merokok. Sedangkan responden yang memiliki pengetahuan kurang baik, ada sebanyak $19(57,6 \%)$ yang berhasil berhenti merokok. Hasil uji statistikchi square, diperoleh nilai $\mathrm{p}$ value $=0,432(>0,05)$ maka dapat disimpulkan bahwa tidak ada hubungan yang signifikan antara pengetahuan dengan keberhasilan berhenti merokok.

Tabel 2. Hubungan Anggota Rumah Tangga yang Tidak Merokok dengan Keberhasilan Berhenti Merokok di Banjar Agung

\begin{tabular}{|c|c|c|c|c|c|c|c|c|}
\hline \multirow{4}{*}{$\begin{array}{l}\text { Variabel } \\
\text { independen }\end{array}$} & \multirow{2}{*}{\multicolumn{4}{|c|}{$\begin{array}{c}\text { Variabel Dependen } \\
\text { Keberhasilan berhenti merokok }\end{array}$}} & \multirow{3}{*}{\multicolumn{2}{|c|}{ Total }} & \multirow{4}{*}{$\begin{array}{l}\text { P- } \\
\text { valu } \\
\text { e }\end{array}$} & \multirow{4}{*}{$\begin{array}{l}\text { OR } \\
\quad(95 \% \mathrm{CI})\end{array}$} \\
\hline & & & & & & & & \\
\hline & \multicolumn{2}{|c|}{ Berhasil } & \multicolumn{2}{|c|}{ Tidak berhasil } & & & & \\
\hline & $\mathrm{n}$ & $\%$ & $\mathrm{n}$ & $\%$ & $\mathrm{~N}$ & $\%$ & & \\
\hline \multicolumn{9}{|c|}{ Anggota Rumah Tangga Yang Tidak Merokok } \\
\hline Ada & 38 & 79,0 & 10 & 20,8 & 48 & 100 & \multirow{3}{*}{0,00} & \multirow{3}{*}{$\begin{array}{c}6,460 \\
2,268-18,398\end{array}$} \\
\hline Tidak ada & 10 & 37,0 & 17 & 63,0 & 27 & 100 & & \\
\hline Jumlah & 48 & 64,0 & 27 & 36,0 & 75 & 100 & & \\
\hline \multicolumn{9}{|l|}{ Pengetahuan } \\
\hline Baik & 29 & 69,0 & 13 & 31,0 & 42 & 100 & \multirow{3}{*}{0,43} & \\
\hline Kurang baik & 19 & 57,6 & 14 & 42,2 & 33 & 100 & & - \\
\hline Jumlah & 48 & 64,0 & 27 & 36,0 & 75 & 100 & & \\
\hline \multicolumn{9}{|l|}{$\begin{array}{l}\text { Perceived } \\
\text { benefit }\end{array}$} \\
\hline Ada & 39 & 76,5 & 12 & 23,5 & 51 & 100 & \multirow{3}{*}{0,00} & \multirow{3}{*}{$\begin{array}{c}5,417 \\
1,896-15,472\end{array}$} \\
\hline Tidak ada & 9 & 37,5 & 15 & 62,5 & 24 & 100 & & \\
\hline Jumlah & 48 & 64,0 & 27 & 34,0 & 75 & 100 & & \\
\hline \multicolumn{9}{|l|}{$\begin{array}{l}\text { Perceived } \\
\text { barrier }\end{array}$} \\
\hline Tidak ada & 31 & 57,4 & 23 & 42,6 & 54 & 100 & \multirow{3}{*}{0,10} & \multirow{3}{*}{ - } \\
\hline Ada & 17 & 81,0 & 4 & 19,0 & 21 & 100 & & \\
\hline Jumlah & 48 & 64,0 & 27 & 36,0 & 75 & 100 & & \\
\hline
\end{tabular}

Hasil analisis hubungan antara perceived benefit dengan keberhasilaan berhenti merokok diperoleh bahwa ada sebanyak $39(76,5 \%)$ responden dengan persepsi positif tentang manfaat berhenti merokok (perceived benefit) yang berhasil berhenti merokok. Sedangkan responden yang tidak ada persepsi positif tentang manfaat berhenti merokok (perceived benefit), ada sebanyak 9 (37,5\%) yang berhasil berhenti merokok. Hasil uji statistic chi square, diperoleh nilai p value
$=0,003(<0,05)$ maka dapat disimpulkan bahwaada hubungan yang signifikan antara perceived benefit dengan keberhasilan berhenti merokok. Dari hasil analisis diperoleh pula nilai $\mathrm{OR}=5,417$, yang artinya responden dengan persepsi positif tentang manfaat berhenti merokok (perceived benefit) memiliki peluang 5,417 untuk berhasil berhenti merokok dibanding dengan responden yang tidak ada persepsi positif tentang manfaat berhenti merokok (perceived benefit). Hasil analisis hubungan perceived barrier dengan keberhasilan 
berhenti merokokok diperoleh bahwa ada sebanyak $31(51,4 \%)$ responden yang tidak ada hambatan untuk berhenti merokok (perceived barrier) berhasil berhenti merokok. Sedangkan responden yang memiliki hambatan untuk berhenti merokok (perceived barrier), ada $17(81,0 \%)$ yang berhasil berhenti merokok. Hasil uji statistik chi square, diperoleh nilai $\mathrm{p}$ value $=0,101(>0,05)$ maka dapat disimpulkan bahwa tidak ada hubungan yang signifikan antara perceived barrier dengan keberhasilan berhenti merokok.

\section{PEMBAHASAN}

\section{Hubungan Anggota Rumah Tangga yang Tidak Merokok terhadap Keberhasilan Berhenti Merokok}

Hasil uji statistik diperoleh nilai $p$ value $=0,001 \quad(<0,05)$ maka dapat disimpulkan bahwa ada hubungan yang signifikan antara anggota rumah tangga yang tidak merokok dengan keberhasilan berhenti merokok. Hasil uji statistik juga diperoleh nilaiOdds Ratio (OR) yaitu 6,460 yang artinya responden dengan anggota rumah tangga yang tidak merokok memiliki peluang 6,460 kali untuk berhasil berhenti merokok dibandingkan dengan yang tidak ada anggota rumah tangga yang tidak merokok.

Hasil penelitian ini, kondisi ekonomi dan sakit akibat rokok menjadi penyebab dari keberhasilan anggota rumah tangga untuk berhenti merokok. Batuk dan sesak napas menjadi penyebab utama anggota rumah tangga untuk berhenti merokok, namun ada beberapa yang kemudian merokok kembali setelah merasa dirinya sudah membaik. Pekerjaan utama responden yang hampir setengahnya merupakan buruh harian lepas dan petani, terkadang membuat anggota rumah tangga yang merokok harus berhenti merokok dalam jangka waktu yang tidak menentu. Hal ini yang kemudian menjadi penyebab responden berhenti merokok walau hanya $49(65,3 \%)$ responden yang berhasil berhenti merokok dan $26(34,7 \%)$ lainnya masih merokok kembali sedikitnya 1 batang dalam 6 bulan terakhir.

Adanya anggota rumah tangga seperti kepala keluarga, suami, mertua atau anak yang tidak merokok dapat menjadi penyebab berhenti merokok anggota rumah tangga lainnya. Berhenti merokok bagi perokok aktif pada dasarnya merupakan hal yang berat. Adiksi nikotin yang terkandung dalam rokok dapat membuat seseorang merokok kembali walau telah terpapar berbagai penyakit (Kementerian Kesehatan Republik Indonesia, 2017). Hasil penelitian (Bahtiar, 2016), mengatakan bahwa perilaku merokok dapat dipengaruhi oleh lingkungan sosial dan keluarga, terutama orang tua. Hasil uji statistik menunjukkan adanya hubungan yang signifikan antara riwayat keluarga dengan motivasi berhenti merokok $\mathrm{p}$ value $=0,001 \quad(<0.05)$. Keluarga dapat memberikan motivasi terhadap anggotanya termasuk perubahan perilaku berhenti merokok. Sehingga keluarga dapat memberikan motivasi sosial kepada anggotanya.

\section{Hubungan Pengetahuan terhadap Keberhasilan Berhenti Merokok}

Hasil uji statistikdiperoleh nilai $\mathrm{p}$ value $=0,432(>0,05)$ maka dapat disimpulkan bahwa tidak ada hubungan yang signifikan antara pengetahuan dengan keberhasilan berhenti merokok. Responden yang memiliki pengetahuan kurang baik sebanyak $19 \quad(57,6 \%)$ dapat berhasil berhenti merokok. Artinya, dengan atau tidak dengan pengetahuan yang baik terkait bahaya merokok dan kandungan bahan kimia yang ada dalam rokok tidak ada hubungannya dengan keberhasilan berhenti merokok. Sebanyak 38 responden yang tidak mengetahui bahwa terdapat 4000 lebih bahan kimia yang terkandung dalam rokok dan dapat menyebabkan penyakit kanker, jantung koroner dan lain sebagainya. Namun sebagian dapat berhasil berhenti merokok, karena alasan utama mereka berhenti bukan terletak dari pengetahuannya saja. Terdapat berbagai kondisi yang mengharuskan mereka 
berhenti merokok tanpa tahu terlebih dahulu bahaya dan kandungan dalam sebatang rokok yang pernah mereka konsumsi.

Pemahaman masyarakat terkait pengetahuan sangat beragam. Pengetahuan seseorang dapat berupa pengetahuan dalam bentuk pengalaman dan pengetahuan yang sudah disimpan dalam bentuk nyata. Pengetahuan dalam bentuk pengalaman biasanya masih tertanam dalam diri seseorang dan tidak bersifat nyata, seperti keyakinan pribadi, perspektif dan prinsip. Pengetahuan yang bersifat nyata berarti pengetahuan yang didapat sudah dideskripsikan dalam tindakan tindakan yang berhubungan dengan kesehatan. Saat seseorang yang tahu tentang bahaya merokok, maka keberhasilan berhenti merokok cenderung besar (Budiman, 2013).

Menurut penelitian (Akmal et al., 2017), banyak siswa yang mengetahui bahaya merokok bagi kesehatan, namun pengetahuan yang dimiliki tidak berbanding lurus dengan perilaku untuk berhenti merokok. Baiknya pengetahuan yang dimiliki oleh responden tidak selalu diterapkan dengan baik pula. Hal ini dapat ditunjukkan dari penelitian yang dilakukan di Banjar Agung, bahwa dari 75 responden sebanyak $20(33,3 \%)$ diantaranya memiliki pengetahuan baik namun tidak berhasil berhenti merokok. Artinya, pengetahuan yang dimiliki belum dapat merubah perilaku responden untuk berhenti merokok.

Hasil penelitian ini sejalan dengan penelitian yang dilakukan (Husna et al., 2020), yang mengatakan bahwa variabel pengetahuan memiliki signifikansi $>0,05$ yaitu 0,052 yang artinya tidak ada hubungan yang signifikan antara pengetahuandengan kesiapan berhenti merokok.Penelitian ini berbanding terbalik dengan penelitian ( $\mathrm{Kn}$ et al., 2019), yang berjudul "Hubungan Tingkat Pengetahuan tentang Dampak Rokok Terhadap Kesehatan Rongga Mulut dengan Tingkat Motivasi Berhenti Merokok pada
Mahasiswa Universitas Kristen Maranatha". Berdasarkan hasil penelitian tersebut, diketahui sebanyak 31 responden yang memiliki pengetahuan baik seluruhnya memiliki motivasi tinggi untuk berhenti merokok. Hasil penelitian yang dilakukan pada 100 responden tersebut menunjukkan adanya hubungan antara tingkat pengetahuan tentang dampak rokok terhadap kesehatan rongga mulut dengan tingkat motivasi berhenti merokok ( $\mathrm{p}$ value $=0,000)$.

Tingkat pengetahuan dapat mempengaruhi seseorang termasuk di dalamnya perilaku seseorang akan pola hidup. Pengetahuan yang dimiliki perokok tentang bahaya dan dampak buruk rokok terhadap kesehatannya akan menjadi pemicu untuk mengurangi tingkat ketergantungan terhadap kebiasaan merokoknya, sehingga tingkat kesehatannya juga akan meningkat. Namun, dalam hal ini pengetahuan yang baik tentang bahaya rokok tidak berbanding lurus dengan perilaku responden untuk berhenti merokok.

\section{Hubungan Perceived Benefit terhadap Keberhasilan Berhenti Merokok}

Hasil uji statistik diperoleh nilai $p$ value $=0,003 \quad(<0,05)$ yang dapat disimpulkan bahwa ada hubungan yang signifikan antara persepsi positif terhadap manfaat berhenti merokok (perceived benefit) dengan keberhasilan berhenti merokok. Hasil uji statistik chi squarejugadiperoleh nilai Odds Ratio (OR) $=5,417$ yang artinya responden yang memiliki persepsi positif tentang manfaat berhenti merokok (perceived benefit) memiliki peluang 5,4 kali untuk berhasil berhenti merokok dibandingkan dengan responden yang tidak memiliki persepsi positif tentang manfaat berhenti merokok.

Perceived benefit berkaitan dengan manfaat yang akan dirasakan jika mengadobsi perilaku baru. Seseorang akan cenderung menerapkan perilaku sehat ketika memiliki kepercayaan bahwa perilaku baru akan mengurangi risiko 
berkembangnya suatu penyakit. Demi mendukung adanya perubahan perilaku seseorang agar berhenti merokok, maka ditanamkan suatu pengertian bahwa banyak manfaat yang akan didapat jika berhenti merokok (Priyoto, 2014).

Hasil penelitian ini sejalan dengan (Husna et al., 2020) yang meneliti faktorfaktor yang mempengaruhi kesiapan berhenti merokok. Didapatkan bahwa, variabel yang berpengaruh secara signifikan pada kesiapan berhenti merokok adalah perceived benefit ( $\mathrm{p}$ value $=0,002$ ). Keyakinan terhadap manfaat yang akan didapatkan saat berhenti merokok merupakan faktor pemicu dari keberhasilan berhenti merokok. Seseorang yang percaya bahwa dengan berhenti merokok dapat membuat tubuh menjadi lebih sehat dan bugar, terhindar dari berbagai penyakit yang diakibatkan oleh merokok seperti batuk-batuk dan penyakit jantung koroner. Suatu persepsi yang positif inilah yang kemudian menjadi pendorong seseorang untuk berhenti merokok.

Penelitian ini menyimpulkan bahwa responden yang merasa dirinya sudah menjadi mantan perokok walau sebagian diantaranya $(34,7 \%)$ masih sering merokok kembali memiliki keyakinan bahwa dengan berhenti merokok maka akan berdampak baik untuk kesehatannya.

\section{Hubungan Perceived Barrier terhadap Keberhasilan Berhenti Merokok}

Hasil analisis dalam penelitian ini menunjukkan bahwa, nilai $\mathrm{p}$ value $=$ $0,101(>0,05)$ yang artinya tidak ada hubungan yang signifikan antara perceived barrier dengan keberhasilan berhenti merokok. Hambatan yang dirasakan berasal dari diri responden sendiri (hasrat untuk merokok kembali), zat adiktif yang menyebabkan ketergantungan sehingga sulit untuk berhenti merokok, lingkungan pergaulan dan tempat tinggal yang kebanyakan adalah perokok, dan kurangnya nasihat dari orang terdekat. Hal ini yang kemudian dirasakan sebagai sebuah pengahalang untuk seseorang melakukan perubahan perilaku kearah yang lebih sehat. Sehingga mantan perokok cenderung akan melakukan aktivitas merokok kembali (Priyoto, 2014). Hasil penelitian ini sejalan dengan penelitian yang dilakukan (Husna et al., 2020), yang mengatakan bahwa variabel perceived barrier memiliki signifikan antara perceived barrier dengan kesiapan berhenti merokok. Hasil penelitian ini berbanding terbalik dengan penelitian (Kumboyono, 2011), yaitu terdapat nilai signifikansi sebesar 0,000 yang artinya terdapat hubungan antara persepsi antara penghambat berhenti merokok (perceived barrier) dengan motivasi berhenti merokok.

Sebagian dari mantan perokok hanya merasa bahwa hasrat/keinginan untuk berhenti merokok atau lingkungan pergaulan serta tempat tinggal saja yang menjadi penghambat untuk berhenti merokok. Sehingga, mereka akan cenderung merokok kembali jika sedang dalam lingkungan atau saat merasa diri butuh sesuatu yang dapat dijadikan pelampiasan emosional yang dirasakan.

\section{KESIMPULAN}

Dapat disimpulkan bahwa Anggota Rumah Tangga yang Tidak Merokok ( $p$ value $0,001<0,005)$ dan Perceived Benefit $(p$ value $0,003<0,005)$ dengan Keberhasilan Berhenti Merokok di Banjar Agung Lampung Selatan. Tidak terdapat hubungan yang signifikan antara Pengetahuan $(p$ value $0,432>0,05)$ dan Perceived Barrier ( $p$ value 0,101 > 0,05) dengan Keberhasilan Berhenti Merokok di Banjar Agung Lampung Selatan. Dalam penelitian ini keberhasilan berhenti merokok dapat tercapai karena perokok sedang dalam keadaan sakit yang diakibatkan oleh rokok atau anggota keluarga mengalami sakit akibat rokok, dan keadaan ekonomi yang sulit. 


\section{UCAPAN TERIMAKASIH}

Ucapan terimakasih saya ucapkan untuk Dosen Pembimbing Utama dan Pembimbinf Pendamping yitu Ibu Dhiny Easter Yanti, S.Kep., M.Kes dan Ibu Fitri Eka Sari, SKM., M.Kes yang telah membantu dalam penyelesaian penelitian dan penulisan hasil penelitian ini.

\section{DAFTAR PUSTAKA}

Aditama, T. Y. (2011). Rokok dan Kesehatan (UI-Press (ed.); 3rd ed.). UIPress.

Akmal, D., Widjanarko, B., \& Nugraha, P. (2017). sikap Mempengaruhi Niat Berhenti Merokok pada Remaja SMA di Kota Bima. Promosi Kesehatan Indonesia, 12, 78-91.

Badan Pusat Statistik. (2019). Profil Statistik Kesehatan 2019. https://ww.bps.go.id/publication/2019/1 2/30/9d583b7e2bd81fada82375e0/profil -statistik-kesehatan-2019.html

Bahtiar, Y. (2016). Keluarga Dapat Memotivasi Mahasiswa Keperawatan Berhenti Merokok. 1-6.

Hastono, S. P. (2006). Analisis Data.

Husna, M. T., Ashari, D. C., Ramadhini, N. N., \& Rodhian, J. (2020). Faktor-Faktor yang Mempengaruhi Kesiapan Berhenti Merokok pada Perokok Usia Dewasa Awal. Ilmu Perilaku, 4, 74-85.

Jatmika, S. E. D., Maulana, M., Kuntoro, \& Martini, S. (2018). Pengendalian Tembakau (F. E. Safrilia (ed.)). KMedia.

Kemenkes RI. (2018). Laporan Provinsi Lampung RISKESDAS 2018.

Kementerian Kesehatan Republik Indonesia. (2017a). Hidup Sehat Tanpa Rokok.

Kementerian Kesehatan Republik Indonesia. (2017b). Upaya Berhenti Merokok (FAQ). http://www.p2ptm.kemenkes.go.id/kegi atan-p2ptm/subdit-penyakit-parukronik-dan-gangguan-imunologi/upayaberhenti-merokok-faq
Kementerian Kesehatan Republik Indonesia. (2017). Warta Kesmas. https://promkes.kemkes.go.id/content/? $\mathrm{p}=7871$

Kementerian Kesehatan Republik Indonesia. (2018). Hasil Utama Riskesdas 208. https://www.litbang.kemenkes.go.id/has il-utama-riskesdas-2018/

Kn, A., Setiawan, I., \& Lelyana, S. (2019). Hubungan Tingkat Pengetahuan Tentang Dampak Rokok Terhadap Kesehatan Rongga Mulut dengan Tingkat Motivasi Berhenti Merokok pada Mahasiswa Universitas Kristen Maranatha. Sound of Dentostry, 3(1), 16-21.

Kumboyono. (2011). Analisis Faktor Penghambat Morivasi Berhenti Merokok Berdasarkan Health Belief Model pada Mahasiswa Fakultas Teknik Universitas Brawijaya Malang. Keperawatan Soedirman, 6(1), 1-8.

Lian, T. Y., \& Dorotheo, U. (2018). The Tobacco Control Atlas ASEAN Regional (B. Ritthiphakdee, M. A. Kolandai, D. Villarreiz, S. Ratanachena, M. M. Cho, W. Jirathanpiwat, \& J. L. Reyes (eds.); Fourth). Southeast Asia Tobacco Control Alliance.

Masturoh, I., \& Anggita, N. (2018). Metodologi Penelitian Kesehatan (R. Y. Priyati (ed.); pertama). Kementerian Kesehatan Republik Indonesia.

Nandika, D. S. (2013). Draf Akhir Rokok Buku Bahaya Merokok Bagi Generasi Muda.

Notoatmodjo, S. (2012). Promosi Kesehatan dan Perilaku Kesehatan (1st ed.). Rineka Cipta.

Peraturan Pemerintah RI. (2012). Peraturanan Pemerintahan Republik Indonesia.

Presiden Republik Indonesia. (2017). Interuksi Presiden Republik Indonesia.

Priyoto. (2014). Teori Sikap \& Perilaku dalam Kesehatan (Pertama). Nuha Medika.

Puskesmas Rawat Inap Banjar Agung. (2020). Data Pre Survei Puskesmas 
Banjar Agung,2020.

Sari, R. P., Sulaeman, \& Angraini, F. (2019). Hubungan Antara Tingkat Pengetahuan Perokok Aktif tentang Bahaya Rokok dengan Motivasi Berhenti Merokok pada Siswa SMA Muhammadiyah Cipondoh. Jurnal Kesehatan, $\quad 8(1), \quad 1-12$. https://doi.org/10.37048/kesehatan.v8i1. 53

Sitinjak, N. E., \& Kurniajati, S. (2018). Perilaku Berhenti Merokok pada Remaja Menurut Teori Health Belief Model. STIKES, 11, 89-160.

Siyoto, S., \& Sodik, M. A. (2015). Dasar Metodologi Penelitian (Ayup-cetakan 1- Yogyakarta (ed.); Cetakan 1). Literasi Media Publishing.

Sugiyono. (2019). Metode Penelitian Kuantitatif Kualitatif dan $R \& D$ (Sutopo (ed.); 1st ed.). Alfabeta.

Suhariyanto. (2015). Statistik Migrasi Jawa Tengah Hasil Survei Penduduk Antar Sensus 2015. Badan Pusat Statistik.

Thabrany, H. (2008). Rokok, Mengapa Haram? Unit Pengendalian Tembakau FKM-UI.

Wibowo, M. (2017). Perspektif Hambatan terhadap Kemungkinan Remaja Berhenti Merokok. Unnes Journal of Public Health, 6(2), 138-140.

World Health Organization. (2010). Trens in Smoking and Quitting in China from 1993 to 2003: National Health Service Survey Data. https://www.who.int/bulletin/volumes/8 8/10/09-064709/en/

World Health Organization. (2019). WHO Report On The Global Tobacco Epidemic, 2019. 